\title{
Cycad diversification and tropical biodiversity
}

\author{
V. RULL \\ Institut Botànic de Barcelona (IBB-CSIC-ICUB), pg. del Migdia, s/n, ES-08038 Barcelona, Spain \\ E-mail: vrull@ibb.csic.es \\ Editor: J. López-Pujol
}

Received 29 February 2012; Accepted 30 April 2012

\begin{abstract}
CYCAD DIVERSIFICATION AND TROPICAL BIODIVERSITY.- The recent unexpected discovery that living Cycadales are not Jurassic-Cretaceous (200-65 Mya) relicts, as all their extant genera began to diversify during the Late Miocene (12 Mya), has challenged a classical evolutionary myth. This brief note shows how this finding may also provide new clues on the shaping of the high tropical biodiversity.
\end{abstract}

Key words: climatic change; Cycadales; latitudinal diversity gradients; paleobiogeography; speciation timing.

\begin{abstract}
Resumen
LA DIVERSIFICACIÓN DE LAS CÍCADAS Y LA BIODIVERSIDAD TROPICAL. - El reciente e inesperado descubrimiento de que las Cycadales actuales no son relictos Jurásico-Cretácicos (200-65 Mya), ya que todos sus géneros iniciaron su diversificación durante el Mioceno Tardío (12 Mya), ha puesto en entredicho un mito evolutivo clásico. En esta nota se expone como este hallazgo puede, además, proporcionar nuevas pistas sobre el origen de la elevada biodiversidad tropical.
\end{abstract}

Palabras clave: cambio climático; cronología de especiación; Cycadales; gradientes latitudinales de biodiversidad; paleobiogeografía.

The ongoing debate regarding the origin of biodiversity patterns on Earth (Hoorn et al., 2010, 2011; Rull, 2011a) may benefit significantly from the latest discovery that extant cycads (Cycadales), traditionally considered as living plant fossils, are remarkably younger than previously expected (Nagalingum et al., 2011). The cycads emerged in the Permian, around 270 million years ago (Mya), and are now represented by approximately 300 extant species of pantropical distribution, with some subtropical representatives (Fig. 1). The cycads have been considered the ancestors of the flowering plants, and are thought to have attained most of their diversity during the JurassicCretaceous (200-65 Mya). However, a molecular phylogenetic study of approximately 200 species recently published by Nagalingum et al. (2011) concludes that extant cycad species originated during the last $12 \mathrm{Myr}$, thus challenging the former view. The evolutionary significance of these results has been highlighted, particularly in terms of morphological stasis, competition with angiosperms, and plant-animal coevolution (Nagalingum et al., 2011; Renner, 2011). Thus far, the emphasis has been placed on the unexpectedly recent initial diversification events 

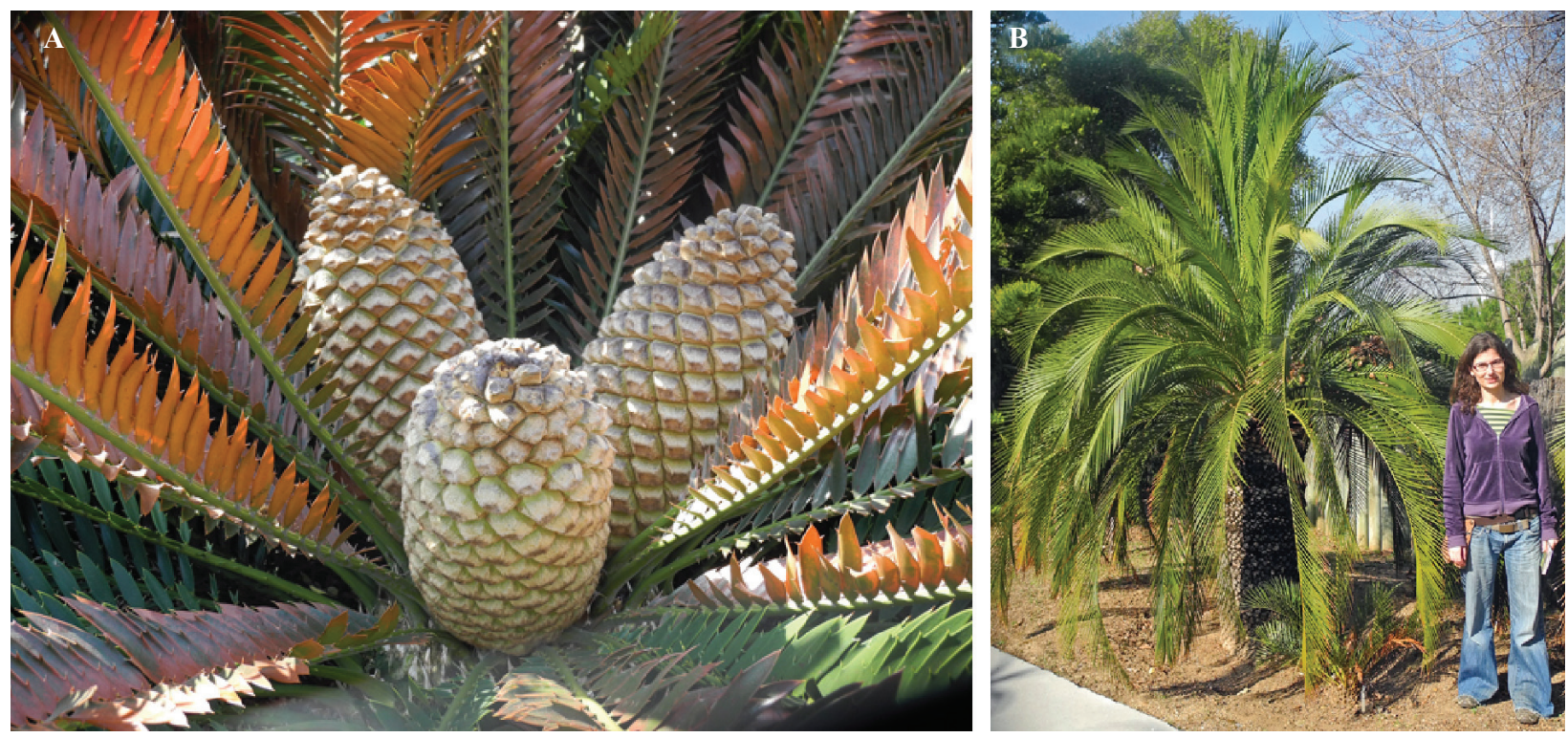

Figure 1. Two examples of cycad species, grown in the Botanical Garden of Barcelona: (A), female cones of Encephalartos lebomboensis I. Verd., from tropical Africa; (B), general view of Macrozamia moorei F. Muell. from tropical Australia.

within each genera and their striking synchrony, but a detailed analysis of the age of origin of individual species reveals interesting clues for the understanding of the origin of tropical biodiversity, as shown in this paper.

A variety of ecological and evolutionary mechanisms have been proposed to explain Earth's latitudinal diversity gradients (Mittelbach et al., 2007) but the ultimate cause for natural selection relies on environmental factors or "agents of selection" (MacColl, 2011). The high level of tropical diversity, especially in the Neotropics, has been a favorite topic since the times of Humboldt and Darwin. Continental drift ruled by plate tectonics has been acknowledged as a fundamental evolutionary agent leading to the waxing and waning of migration barriers and pathways and determining new chances for vicariance or gene flow, as well as for colonization opportunities on newly created mountain and island habitats. Climate changes are thought to have shaped similar evolutionary outcomes via such changes as altitudinal, latitudinal, and sea-level shifts (Rull, 2011b).

The recent development of molecular dating techniques has revitalized the controversy between the defenders of either Quaternary (the last 2.6 Myr) climatic changes or Neogene (the period between 23.0 and 2.6 Mya, comprising the Miocene and the
Pliocene, with a boundary of 5.3 Mya) tectonically driven paleogeographic reorganizations as speciation agents. Comprehensive surveys, however, favor a complex interaction of these agents on different spatial and temporal scales (Rull, 2008). The study by Nagalingum et al. (2011) shows that the diversification within the extant cycad genera (or the crown diversification) occurred during the Late Miocene - between approximately 10 and 5 Mya-, with the exception of Ceratozamia Brongn., whose diversification initiated in the Pliocene. Therefore, crown dating suggests that Neogene speciation agents would have been important in the initial diversification of extant cycads.

Nagalingum et al. (2011) performed species dating as well, thus allowing a more careful examination of the complexity of speciation trends. However, these data have not yet been exploited to their full potential. Globally, $26(13.2 \%)$ of the extant cycad species studied originated in the Late Miocene, 98 (49.8\%) originated in the Pliocene and $67(34.0 \%)$ originated in the Pleistocene; in other words, more than a tenth of living cycad species originated after $12 \mathrm{Mya}$, almost the half originated after $5 \mathrm{Mya}$, and more than a third are less than 2.6 million years old (Fig. 2). Among the genera, Pliocene species dominate in Encephalartos Lehm. (32 sp., 60.4\%), Cycas L. (38 sp., 59.4\%) and Mac- 


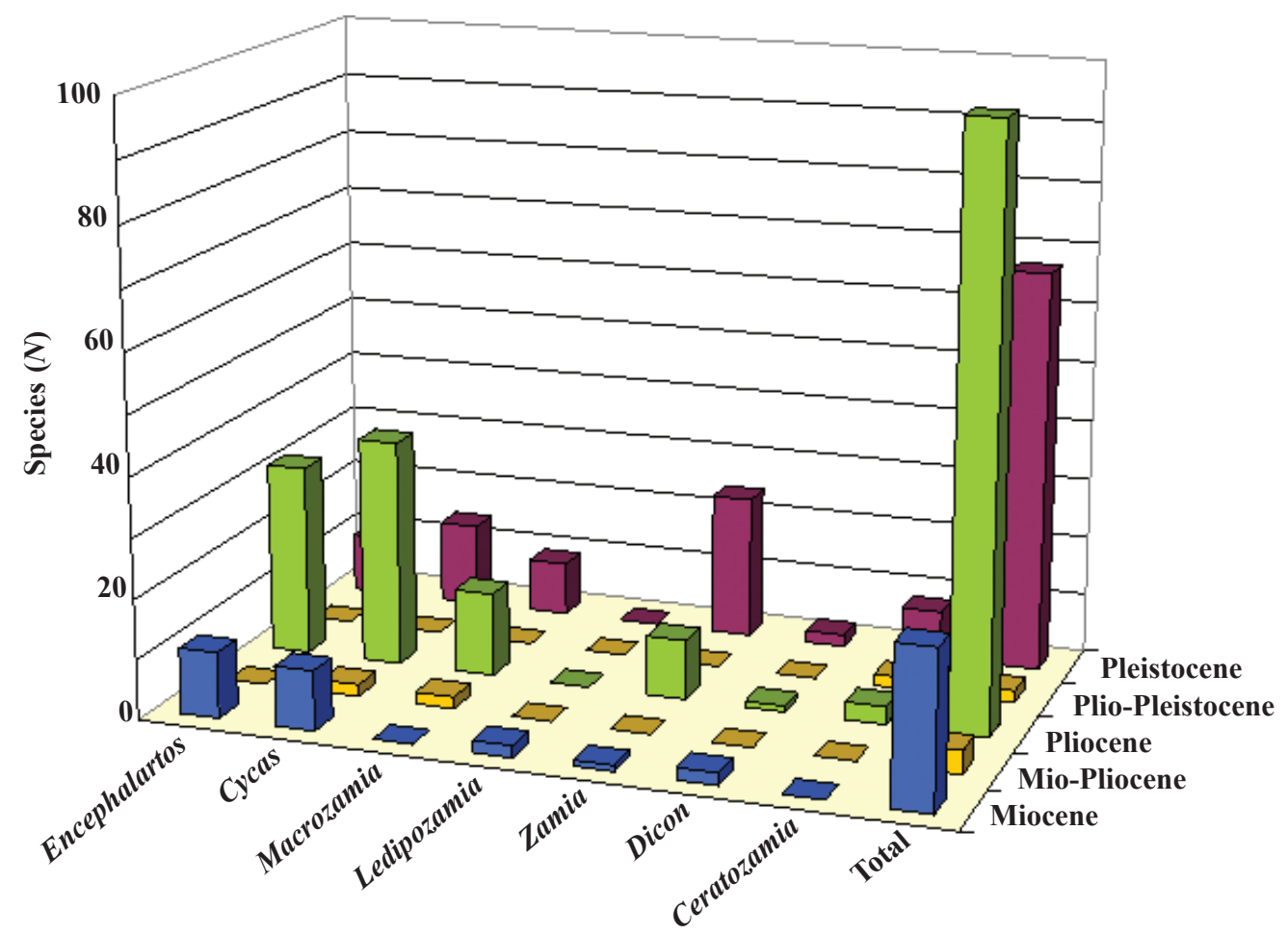

Figure 2. Histogram showing the number of extant cycad species originated since the Late Miocene to the Pleistocene, based on the raw data from Nagalingum et al. (2011). Only genera with more than one species studied are included.

rozamia Miq. (14 sp., 56.0\%), whereas Pleistocene species predominate in Zamia L. (24 sp., 68.6\%) and Ceratozamia (67 sp., 40.0\%). Late Miocene speciation is not dominant but is significant in Encephalartos (11 sp., 20.8\%) and Cycas (10 sp., $15.6 \%$ ), whereas Pleistocene speciation is also important in these two genera (10 sp., $18.9 \%$ and 14 sp., 21.9\%, respectively) and in Macrozamia (9 sp., 36.0\%). From a biogeographical perspective, Pliocene speciation dominates in Africa (32 sp., 60.4\%) and Australasia (52 sp., 57.1\%), whereas Pleistocene speciation prevails in the Neotropics (34 sp., 64.2\%). Conversely, Miocene speciation is comparatively low, averaging $\sim 13 \%$ in the three regions. Of note, approximately two thirds of living neotropical cycad species originated in the Pleistocene, whereas approximately one quarter are of Pliocene origin (only $\sim 5 \%$ emerged during the Miocene).

In summary, the conclusion of Nagalingum et al. (2011) that extant cycad diversity originated since the Late Miocene can be further pushed by a detailed analysis of their own data at species level, which shows that more than $80 \%$ of these species are even more recent and have originated during the Pliocene $(<5 \mathrm{Mya})$ and the Pleistocene ( $<2.6 \mathrm{Mya})$. These a priori unexpectedly high rates of Pliocene and Pleistocene diversification have been explained in terms of climate, as a consequence of: (1) changes in general circulation patterns, due to the attainment of a paleogeographic configuration similar to the present, which developed in more seasonal climates, and (2) a significant global cooling that initiated around the Mio-Pliocene ( $\sim 5 \mathrm{Mya})$ and led to Pleistocene glaciations (Nagalingum et al., 2011; Renner, 2011).

Hence, there is more than the end of a classical evolutionary myth in the findings of Nagalingum et al. (2011). They also show that, even in a lineage as old as the cycads, most of the extant tropical biodiversity has been originated after $\sim 5$ Mya, when climate changes have been the norm. It is particularly striking the large proportion of species emerged during the Pleistocene (especially in the Neotropics), when glacial-interglacial cycles have been the dominant environmental forcing. Most arguments denying Quaternary speciation and favoring Neogene diversification are based on 
crown dating alone (Hoorn et al., 2010; Wesselingh et al., 2010). The case of cycads reinforces the view that both crown and individual species dating are needed to unravel the complexity of diversification, both in the tropics and in extratropical regions (Rull, 2011b). Indeed, molecular phylogenetic evidence on Pleistocene speciation in relation to climate shifts is growing elsewhere (e.g. Weir \& Schluter, 2007; Janssens et al., 2009; Valente et al., 2010; Mullen et al., 2011). The role of the different speciation agents in the shaping of present-day biodiversity patterns should be addressed taking into account that biodiversity is made of species and sub-specific clades, and any study on this subject should be based on specific and sub-specific categories rather than on genera and other supra-specific taxa (Rull, 2012).

\section{ACKNOWLEDGEMENTS}

Funding has been provided by projects CGL2009-07069/BOS (Ministry of Science and Innovation) and BIOCON 08-031 (BBVA Foundation).

\section{REFERENCES}

Hoorn, C., Wesselingh, F. P., ter Steege, H. et al. 2010. Amazonia through time: Andean uplift, climate change, landscape evolution, and biodiversity. Science 330: 927-931.

Hoorn, C., Wesselingh, F. P., Ter Steege, H. et al. 2011. Origins of Biodiversity-Response. Science 331: 399-400.

Janssens, S. B., Knox, E. B., Huysmans, S., Smets, E. F. \&
Merckx, V. S. F. T. 2009. Rapid radiation of Impatiens (Balsaminaceae) during Pliocene and Pleistocene: Result of a global climate change. Mol. Phylogenet. Evol. 52: 806-824.

MacColl, A. D. C. 2011. The ecological causes of evolution. Trends Ecol. Evol. 26: 514-522.

Mittelbach, G. G., Schemske, D. W., Cornell, H. V. et al. 2007. Evolution and the latitudinal diversity gradient, speciation, extinction and biogeography. Ecol. Lett. 4: 315-331.

Mullen, S. P., Savage, W. K., Wahlberg, N. \& Willmott, K. R. 2011. Rapid diversification and not clade age explains high diversity in neotropical Adelpha butterflies. Proc. R. Soc. B 278: 1777-1785.

Nagalingum, N. S., Marshall, C. R., Quental, T. B., Rai, H. S., Little, D. P. \& Mathews, S. 2011. Recent synchronous radiation of a living fossil. Science 334: 796-799.

Renner, S. S. 2011. Living fossil younger than thought. Science 334: 766-767.

Rull, V. 2008. Speciation timing and neotropical biodiversity, the Tertiary-Quaternary debate in the light of molecular phylogenetic evidence. Mol. Ecol. 17: 2722-2729.

Rull, V. 2011a. Origins of biodiversity. Science 331: 398-299.

Rull, V. 2011b. Neotropical biodiversity: timing and potential drivers. Trends Ecol. Evol. 26: 508-513.

Rull, V. 2012. Palaeobiodiversity and taxonomic resolution: linking past trends with present patterns. J. Biogeogr. 39: 1005-1006.

Valente, L. M., Savolainen, V. \& Vargas, P. 2010. Unparalleled rates of species diversification in Europe. Proc. R. Soc. B 277: 1489-1496.

Weir, J. T. \& Schluter, D. 2007. The latitudinal gradient in recent speciation and extinction rates of birds and mammals. Science 315: 1574-1576.

Wesselingh, F. P., Hoorn, C., Kroonenberg, S. B., Antonelli, A., Lundberg, J. G., Vonhof, H. B. \& Hooghiemstra, H. 2010. On the origin of Amazonian landscapes and biodiversity, a synthesis. In: Hoorn, C. \& Wesselingh, F. (Eds.), Amazonia, landscape and species evolution. Wiley-Blackwell, Oxford: 421-431. 